it seems likely that usually crippled individuals would be selected. The number of shot-crippled ducks is high, the number carrying lead shot but appearing to be healthy is even higher. Lloyd Keith states that "crippled ducks still surviving in open waterholes were constantly harassed" by wintering Snowy Owls (Keith, L. B. 1960. Observations on Snowy Owls at Delta, Manitoba. Can. Field Nat., 74: 106-112). Capture of free-flying ducks, as described above, must be rather unusual. At any rate, it seems reasonable to accept an oc- casional loss to an owl, meanwhile applauding their regular forays on the mouse populations. For us, that clear, cold day on Goose Island was a memorable event; the small duck speeding across the ice and out of sight, the owl in swift pursuit: these were the participants in a scene of breathtaking, fleet-winged skill and beauty. There was an inherent beauty, too, in the calm, deliberate way in which the owl sat and plucked at its prey-by these ancient patterns of behavior, energy is transferred from duck to owl.

\title{
Recollection of An Encounter Between a Golden Eagle and a Great Blue Heron
}

\section{by Dave Santy, Beechy}

On a sunny summer afternoon a few years ago while I was working in my garden two young lads, Alex Covey and Kenny Whidden, brought to me a large bird for identification. I readily recognized it as a Golden Eagle. The bird was in very bad condition and was gasping its last breath. The wet feathers that clung to the skin revealed that it was badly torn. The boys told me of having witnessed a fight between the eagle and a Great Blue Heron beside a pond formed by a dam across a coulee just north of the village of Beechy. The pond was a favourite watering and feeding place for many birds and other animals. Besides other forms of aquatic life it was heavily populated by salamanders which were a tidbit for the large wading heron, and no doubt also for the eagle. This was all well known to the boys who were wont to crawl up from the low side of the dam and peer through the trees to see the antics of the various daily visitors.

At this time it would seem that all the other denizens of the pond had taken fright and had fled from the fury of the battle. The struggle between the eagle and the heron had apparently been going on for some time before the boys came on the scene. Evidence indicated that it had started in the water at the edge of the pond where the soft earth was much scratched and marked. Now, in the final rounds, the struggling pair had moved back farther and onto the grass. As the boys described it to me, the heron was more or less on its side, while the eagle was sitting upright on its outspread tail, braced by its feet. The eagle made no use of its beak as a weapon but rather depended on its fairly long legs and taloned feet to ward off the rapierlike thrusts of the long and sharp bill of the heron. Repeatedly, the long, arched neck of the heron would whip out and fairly knock its adversary off balance as well as tearing its flesh. The boys watched in amazement but it was now noticeable to them that the heron was showing exhaustion. Following one thrust it failed to recoil its neck; the head trailed to the ground, ard at once the talons of the eagle closed on it. The fight over, the boys ran to the corner of the closely woven wire fence to get the help of post braces to climb over; by the time they got to the birds the heron was dead. Its opponent, the eagle, was also dead within a few minutes of their bringing it to me.

\section{ANNUAL MEETING}

The S.N.H.S. will hold its 1964 annual meeting in the Saskatchewan Museum of Natural History, on Octaber 17. Please plan to attend, to hear reports of officers and committees and to help plan future activities of the society. 